\title{
Contextual analysis and epidemiology of spider bite in southern Santa Catarina State, Brazil
}

\author{
Maykon P. Cristiano ${ }^{a}$, Danon C. Cardoso ${ }^{\text {b,*}}$, Melissa S. Raymundo ${ }^{c}$
}

\author{
a Programa de Pós-graduação em Genética e Melhoramento, Universidade Federal de Viçosa - UFV, P.H. Rolfs s/n, Dep. de \\ Biologia Geral, Viçosa, MG, 36570-000, Brazil \\ b Programa de Pós-graduação em Entomologia, Universidade Federal de Viçosa - UFV, P.H. Rolfs s/n, Dep. de Biologia Animal, \\ Viçosa, MG, 36570-000, Brazil \\ c Universidade Estadual do Centro-Oeste do Paraná - UNICENTRO, Rua Simão Varela de Sá, Campus do Cedeteg, Guarapuava, \\ PR, 85040-080, Brazil
}

Received 15 January 2009; received in revised form 11 March 2009; accepted 13 March 2009

Available online 16 April 2009

\section{KEYWORDS \\ Spiders; \\ Spider bite; \\ Loxosceles; \\ Poisonous animals; \\ Public health; \\ Brazil}

\begin{abstract}
Summary The aim of this work was to conduct an epidemiological and clinical review of 1126 cases of envenoming by spider recorded in the national notifiable diseases information system (SINAN) files of the Municipal Health Secretary of the Criciúma region, Santa Catarina State, Brazil from 1994 to 2006 . This work presents a critical analysis carried out by the application of the $\chi^{2}$ test, with different regional contextual parameters, including the incidence coefficient. Spider envenoming accounts for more than $50 \%$ of all cases recorded in the SINAN files for poisonous animals and is the main cause of human envenomation in the Criciúma region. The majority of the spider bites $(57.4 \%)$ were reported in the hottest months, from December to May. The anatomic region that suffered the most bites was the hand. Nearly $50 \%$ of the accidents were recorded in the group aged 20-49 years. The spiders most frequently involved in accidents for all age groups were of the Loxosceles genus. Although the data collected lack further epidemiological and, especially, clinical details, this does not affect the conclusions of the study, which could be used in the planning of actions aimed at improving environmental health. (c) 2009 Royal Society of Tropical Medicine and Hygiene. Published by Elsevier Ltd. All rights reserved.
\end{abstract}

\section{Introduction}

Poisonous animals (snakes, scorpions and spiders) are among the agents most often responsible for human poisoning in

\footnotetext{
* Corresponding author. Tel.: +55 3186686955.

E-mail addresses: danonclemes@hotmail.com, danon.cardoso@ufv.br (D.C. Cardoso).
}

Southeast Asia, Africa and tropical America. ${ }^{1}$ In these countries, epidemiological studies regarding poisonous animals are generally restricted to snake bites, and little information about other poisonous animals is available. ${ }^{2-5}$ In Brazil, accidents with poisonous animals are a leading cause of human envenomation, exceeded only by poisoning through medication. 6,7

In 1986 there was a crisis in the production of antivenoms in Brazil; consequently the Ministry of Health created 
the National Program for the Control of Accidents due to Poisonous Animals, under which the recording by hospitals and health centres of accidents with snakes became obligatory. However, only in 1988 were accidents with scorpions and spiders included in the notification system. ${ }^{8}$

In Brazil, three genera of spider are considered of importance to medicine: Loxosceles, Phoneutria and Latrodectus. However, other genera are involved in accidents, for example, crab spiders of several genera and the Lycosa genus, but have little importance for human envenoming. In southern Brazil, in studies carried out in Paraná State, accidents involving spiders of the genus Loxosceles were more frequent than those with other spiders. Andrade et al. ${ }^{9}$ described Loxosceles intermedia as the predominant species in the urban regions of Paraná and Santa Catarina State.

Epidemiological data are of considerable importance for the implementation of education and prevention programs. Prevention is a powerful tool for improving the quality of life of the population through the manipulation of factors that impact on human health. ${ }^{10}$ Thus, the aim of this article was to acquire knowledge regarding certain aspects of the epidemiology and injuries resulting from spider bites in the southern region of Santa Catarina State, Brazil.

\section{Materials and methods}

\subsection{Studied area}

The study area is located between the southern parallels $25^{\circ} 57^{\prime} 41^{\prime \prime}$ and $29^{\circ} 23^{\prime} 55^{\prime \prime}$ and the western meridians $48^{\circ} 19^{\prime} 37^{\prime \prime}$ and $53^{\circ} 50^{\prime} 00^{\prime \prime}$ in the Atlantic forest. The climate is mesothermal, with temperatures ranging from 6 to $36^{\circ} \mathrm{C}$, rainfall is distributed throughout the entire year and totals $1200-1660 \mathrm{~mm} /$ year, and there are well-defined seasons. ${ }^{11,12}$ The region of study is composed of 11 municipalities (Içara, Lauro Müller, Morro da Fumaça, Nova Veneza, Siderópolis, Urussanga, Forquilhinha, Cocal do Sul, Treviso, Orleans and Criciúma) and the total occupied area is around $2640000 \mathrm{~km}^{2}$. The human population is around 340000 and the majority of the municipalities are predominantly rural. ${ }^{13}$

\subsection{Epidemiological and clinical information}

Epidemiological information regarding spider bites and poisonous animal accidents from 1994 to 2006 was prospectively collected from the SINAN (System of Injury Notification Information) files of the Municipal Health Secretary of Criciúma region. SINAN recordings, processes and makes available for the public health system data concerning notifiable incidents such as dengue fever, AIDS and accidents with poisonous animals. The SINAN Individual Notification Form is completed at the health centre (by any healthcare professional, for example, a nurse, doctor, technician, etc.) for each patient at the time of treatment. Later, the data are transferred to a database (SINAN system) at the Municipal Health Secretariat.

Data regarding age, gender, origin (rural or urban), bite site, case evolution, case classification, time to receiving care, treatment, activity type (work or leisure) and frequency per season were collected. The data were collated separately for spider genera medically important in Brazil,
Loxosceles, Phoneutria and Latrodectus, whereas data for other spiders of lesser importance were included in a single category, other genera, including Lycosa, for example.

\subsection{Data analysis}

The frequency of results for each variable studied and the incidence coefficient for the period of the study were calculated. For the 1994 population we used data from the 1991 Brazilian Geographical Statistics Institute (IBGE) census, adding a 1.24\% growth per year until 1996; for subsequent years the 1996 census was used for the calculation until 1999 and the 2000 census was used to calculate up to 2006, with annual growth of $2.08 \%$ and $0.98 \%$ a year, respectively.

Statistical analysis was performed using the $\chi^{2}$ test to verify similarities between the proportions reported for the groups of genera of spiders, using STATISTICA 98 (StatSoft, São Caetano do Sul, SP, Brazil); $P$-values of $\leq 0.05$ were considered significant.

\section{Results}

\subsection{Epidemiological data}

From 1994 to 2006 a total of 1926 accidents involving poisonous animals were notified in the study area. Of these, 1126 were cases of envenomation by spiders, representing $58.5 \%$ of all cases recorded in the SINAN files, compared with $320(16.6 \%)$ cases of poisoning by snakes. Spider envenoming is the main cause of human envenomation in the Criciúma region. The incidence coefficients (per thousand inhabitants) for spider bites from 1994 to 2006 were 0.02 , $0.06,0.12,0.10,0.09,0.24,0.17,0.35,0.36,0.40,0.41$, 0.49 , and 0.41 , respectively.

The spiders involved were identified in just 331 of the 1126 cases notified to the Municipal Health Secretary, where 52 cases were accidents involving the Phoneutria genus, 222 cases with the Loxosceles genus, 5 with Latrodectus and 52 cases with spiders of other genera (including spiders of the Lycosa genus) (Table 1). Even with the low percentage of identification of the spider, the data corroborate those of previous studies. ${ }^{14-16}$ The Loxosceles genus is the predominant agent of human envenomation (67.1\% of cases) in southern Santa Catarina State.

The majority of spider bites $(57.4 \%, n=190)$, for all genera, were reported in the hottest months, from December to May (Table 1), these months representing the summer and the beginning of autumn in tropical regions, a period in which these animals increase their activity. ${ }^{17}$ In the coldest months a lower frequency of accidents was recorded (42.6\%, $n=141, P<0.001)$. These data corroborate studies with snakes, in which the frequency of accidents increases markedly in the hottest months; however, spider bites do not show as drastic a reduction in winter and spring as that reported for snake bites. ${ }^{18,19}$

Interestingly, spider bites were as frequent in women as in men, with a male/female ratio of 1.0:1.02 $(P=0.95)$. The anatomic region that suffered the most bites from the Loxosceles genus was the hand $(32.4 \%, n=72)$, followed by the legs, arms and foot. Other regions, such as the head, were less frequently affected. For the Phoneutria genus, 
Table 1 Epidemiological data of spider bites 1994-2006 in Criciúma region, Santa Catarina State, Brazil

\begin{tabular}{|c|c|c|c|c|c|c|}
\hline & $\begin{array}{l}\text { Phoneutria } \\
(n=52)\end{array}$ & $\begin{array}{l}\text { Loxosceles } \\
(n=222)\end{array}$ & $\begin{array}{l}\text { Latrodectus } \\
(n=5)\end{array}$ & $\begin{array}{l}\text { Other genera } \\
(n=52)\end{array}$ & $\begin{array}{l}\text { Total } \\
(n=331)^{\mathrm{a}}\end{array}$ & $\begin{array}{l}\text { Frequency } \\
(\%)\end{array}$ \\
\hline \multicolumn{7}{|l|}{ Season } \\
\hline Dec-Feb & 15 & 59 & 1 & 13 & 88 & 26.6 \\
\hline Mar-May & 16 & 69 & 2 & 15 & 102 & 30.8 \\
\hline Jun-Aug & 11 & 42 & 2 & 12 & 67 & 20.2 \\
\hline Sep-Nov & 10 & 52 & 0 & 12 & 74 & 22.4 \\
\hline \multicolumn{7}{|l|}{ Gender } \\
\hline Female & 26 & 112 & 2 & 27 & 167 & 50.5 \\
\hline Male & 26 & 110 & 3 & 25 & 164 & 49.5 \\
\hline \multicolumn{7}{|l|}{ Age (years) } \\
\hline $0-9$ & 1 & 26 & 0 & 10 & 37 & 11.2 \\
\hline $10-19$ & 6 & 31 & 2 & 10 & 49 & 14.8 \\
\hline $20-49$ & 27 & 116 & 2 & 20 & 165 & 49.8 \\
\hline $50-79$ & 18 & 45 & 1 & 11 & 75 & 22.7 \\
\hline$\geq 80$ & 0 & 4 & 0 & 1 & 5 & 1.5 \\
\hline \multicolumn{7}{|l|}{ Bite site } \\
\hline Head & 1 & 11 & 0 & 2 & 14 & 4.2 \\
\hline Hand & 21 & 72 & 3 & 27 & 123 & 37.2 \\
\hline Arm & 2 & 37 & 1 & 6 & 46 & 13.9 \\
\hline Leg & 5 & 55 & 1 & 8 & 69 & 20.8 \\
\hline Foot & 20 & 34 & 0 & 7 & 61 & 18.4 \\
\hline Other & 3 & 13 & 0 & 2 & 18 & 5.4 \\
\hline
\end{tabular}

a further 795 spider bites were identified from 1994 to 2006; however, the data were not used in the analysis because the spider genera were unknown.

two anatomic regions, the hand and foot, presented the most bites, with a total of $78.8 \%(n=41)$. The hand $(51.9 \%)$ was the body site most affected by spiders of the other genera. Results of the $\chi^{2}$ test demonstrated that the hands and legs were more frequently affected by the Loxosceles genus than by other genera $(P<0.001)$. A further observation was a higher accident frequency of $49.8 \%(n=165)$ recorded in the 20-49 years age group, which was statistically significant $(P<0.001)$ for all cases and also for each genus separately (Table 1). The spiders most involved in accidents for all age groups belonged to the Loxosceles genus.

\subsection{Clinical and contextual features}

In the Criciúma region the victims reported two main activities at the time of the bite: work and leisure (Table 2 ) and there was no significant difference $(P=0.30)$ between the frequency of the activities. The victims were mainly from urban areas $(70.1 \%, P<0.001)$.

For all genera, the majority of patients $(64.4 \%)$ had mild envenoming (Table 3). Severe envenomation occurred in 19 patients and only with bites from Phoneutria and Loxosceles spp. Moreover, this was significantly more frequent after bites from the Loxosceles genus (18 patients, $P<0.001$ ). The seeking of medical care decreased with time for all spider genera except Loxosceles. Medical care sought $12 \mathrm{~h}$ or more from the time of the accident was more frequent in victims of accidents with Loxosceles spiders, followed by 6-12 $\mathrm{h}$ after the bite, but this difference was not significant. Moreover, it was found that 118 (35.6\%) of the cases were attended after $6 \mathrm{~h}, 105(89 \%)$ of which resulted from injuries involving the Loxosceles genus (Table 3 ).

Table 2 Origin and activity of the 331 victims at the time of the spider bite

\begin{tabular}{|c|c|c|c|c|c|c|}
\hline & $\begin{array}{l}\text { Phoneutria } \\
(n=52)\end{array}$ & $\begin{array}{l}\text { Loxosceles } \\
(n=222)\end{array}$ & $\begin{array}{l}\text { Latrodectus } \\
(n=5)\end{array}$ & $\begin{array}{l}\text { Other genera } \\
(n=52)\end{array}$ & $\begin{array}{l}\text { Total } \\
(n=331)\end{array}$ & $\begin{array}{l}\text { Frequency } \\
(\%)\end{array}$ \\
\hline \multicolumn{7}{|l|}{ Area } \\
\hline Urban & 33 & 157 & 5 & 37 & 232 & 70.1 \\
\hline Rural & 19 & 65 & 0 & 15 & 99 & 29.9 \\
\hline \multicolumn{7}{|l|}{ Activity } \\
\hline Work & 26 & 84 & 3 & 24 & 137 & 41.4 \\
\hline Leisure & 18 & 88 & 2 & 15 & 123 & 37.2 \\
\hline Other & 8 & 50 & 0 & 13 & 71 & 21.5 \\
\hline
\end{tabular}


Table 3 Envenoming grade, management and evolution of cases of spider bite

\begin{tabular}{|c|c|c|c|c|c|c|}
\hline & $\begin{array}{l}\text { Phoneutria } \\
(n=52)\end{array}$ & $\begin{array}{l}\text { Loxosceles } \\
(n=222)\end{array}$ & $\begin{array}{l}\text { Latrodectus } \\
(n=5)\end{array}$ & $\begin{array}{l}\text { Other genera } \\
(n=52)\end{array}$ & $\begin{array}{l}\text { Total } \\
(n=331)\end{array}$ & $\begin{array}{l}\text { Frequency } \\
\text { (\%) }\end{array}$ \\
\hline \multicolumn{7}{|l|}{ Envenoming grade ${ }^{a}$} \\
\hline Mild & 41 & 122 & 4 & 46 & 213 & 64.4 \\
\hline Moderate & 10 & 82 & 1 & 6 & 99 & 29.9 \\
\hline Severe & 1 & 18 & 0 & 0 & 19 & 5.7 \\
\hline \multicolumn{7}{|l|}{$\begin{array}{l}\text { Time to receiving } \\
\text { medical care } \\
(\mathrm{h})^{\mathrm{b}}\end{array}$} \\
\hline $0-1$ & 26 & 36 & 0 & 23 & 85 & 25.7 \\
\hline$>1-3$ & 12 & 42 & 1 & 12 & 67 & 20.2 \\
\hline$>3-6$ & 7 & 12 & 3 & 4 & 26 & 7.9 \\
\hline$>6-12$ & 2 & 47 & 0 & 1 & 50 & 15.1 \\
\hline$>12$ & 3 & 58 & 0 & 7 & 68 & 20.5 \\
\hline \multicolumn{7}{|l|}{ Management } \\
\hline Received antivenom & 6 & 49 & 0 & 5 & 60 & 18.1 \\
\hline No Antivenom & 46 & 173 & 5 & 47 & 271 & 81.9 \\
\hline \multicolumn{7}{|l|}{ Case evolution } \\
\hline Cure & 51 & 217 & 5 & 49 & 322 & 97.3 \\
\hline Cure with sequelae & 1 & 4 & 0 & 3 & 8 & 2.4 \\
\hline Death & 0 & 1 & 0 & 0 & 1 & 0.3 \\
\hline
\end{tabular}

In the great majority of the cases notified the victims did not receive antivenom $(81.9 \%, n=271)$, and in the large majority of cases $(97.3 \%, n=322)$ they recovered, with only eight cases $(2.4 \%)$ recovering with complications and only one death (Table 3).

\section{Discussion}

Species of poisonous spider are found throughout the world, mainly in subtropical and tropical regions. In the Criciúma region 1126 spider bites were recorded from 1994 to 2006 . In just 331 cases was the spider genus recognized. Nonetheless, the behavioural profile of the unidentified reports followed the pattern of those cases where the spider responsible was identified. Considering the 331 cases as a sample of a total population of 1126 cases, the proportions and relationships reported can be considered to have an experimental error for the population of less than $2 \%$, assuming a level of significance of $95 \% .20$

The low rate of spider genus identification occurred either because the victims did not know how to describe the animal correctly or because the healthcare workers did not have sufficient specific knowledge to make an identification. Our data allow the identification of the animal based on two available parameters - the victim's report and the clinical assessment. Information from the database does not tell us if spiders were brought in with the patient. In the majority of cases the spider genus identification was based on careful evaluation of historical and clinical findings and the exclusion of other aetiologies. ${ }^{14}$

In the study region, spider bite was the main cause of human envenomation, a tendency similar to that observed in other studies. ${ }^{10,14,16}$ The Loxosceles genus resulted in most injuries in the Criciúma region, these data corroborating those from other studies carried out in the southern region of Brazil, including Paraná, Santa Catarina and Rio Grande do Sul states. ${ }^{10,14-16}$ Worldwide, approximately 20 of 200 arachnid genera can cause severe human poisoning and the Loxosceles genus is widespread, with more than 100 species distributed across the globe. ${ }^{21,22}$ Furthermore, many studies on spider distribution have found a greater number of species living around homes, increasing the likelihood of contact with these animals and humans. ${ }^{23}$

The number of recorded spider bites increased between 1994 and 2006. This may simply be the result of the increase in the local human population; in 1991 the population was around 290000 , whereas today the region is home to a population of 370000 people. However, the increase in the number of accidents does not appear to be correlated only with increasing population, since the incidence of accidents per 1000 inhabitants nearly doubled from 1999, which does not reflect the rise in the human population, which saw an average growth rate of only $0.98 \%$ per year over the same period. The expansion of cities and their disorderly development may be one of the factors in the increase in spider bites, since with the destruction of their natural habitat the animals begin to inhabit urban environments. ${ }^{24}$

Accidents were more frequent in the hottest months, from December to May, consistent with patterns reported in studies carried out with spiders and other poisonous animals such as scorpions, snakes, caterpillars and honey bees. ${ }^{10,18,25}$ This seasonality of bites has several interwoven causes in the Criciúma region: overlap with the period of highest rainfall and temperatures, increased activity of spiders (reproduction), and increased agricultural activity. ${ }^{26}$ 
The distribution of accidents showed the highest concentration of cases in urban areas, accounting for over two-thirds of the reports. This is because the accidents occurred in the house, when the victims were performing domestic tasks. We observed that over $40 \%$ of the victims were injured while working. Some studies have shown that spiders in urban areas have synanthropic habits, living in peridomiciliary and intradomiciliary regions. ${ }^{23,27}$ According to Diaz, ${ }^{28}$ spider bites can usually be prevented by simple personal and domestic measures. Another possible reason for these results may be underreporting from rural areas, where the population has poor access to health services and information. ${ }^{26}$

The anatomical location of spider bites was found to depend more on the occasion of the accident and the activity of the victims at the time of the bite than on the preference of the biting spider. ${ }^{28,29}$ The site of the bite is simply a result of chance. Besides, a higher accident frequency in victims aged 20-49 years and 10-19 years reflects the groups who are more active in the house, where the majority of accidents occur. Accidents occur less frequently in older people, babies and children under 9 years old because these age groups carry out few or no domestic tasks. These results are consistent with data from the literature for spiders and other poisonous animals. ${ }^{10}$

The clinical picture in the majority of victims was mild, and few cases with moderate or serious envenoming were recorded. The use of antivenom therapy was largely avoided due to complications that may result from anaphylactic reactions and, in any case, its efficiency is reduced $36 \mathrm{~h}$ after the bite. ${ }^{14,30}$ Only eight patients had complications after recovery. One patient died following envenoming by a spider of the Loxosceles genus. In relation to this single death no further comment can be made because the database does not contain details of the cause of death. Loxocelism is a necrotizing-haemolytic syndrome resulting from bites from spiders of the genus Loxosceles and is the most severe form of spider envenomation in Brazil and other countries of South America. ${ }^{14}$

The victims sought medical care close to the time of the accident or up to $3 \mathrm{~h}$ after being bitten by Latrodectus and Phoneutria spp. and other spiders, however, for Loxosceles spp., medical attention was sought up to $12 \mathrm{~h}$ or more after the accident. This is because accidents with other genera result in acute pain at the time of the bite, while Loxosceles bites possess a different clinical profile. ${ }^{30,31}$ The Loxosceles bite is relatively painless at the moment of the accident; many patients do not feel the bite and seek medical attention either when the pain becomes more severe after $2-8 \mathrm{~h},{ }^{17}$ or when the skin lesions appear. ${ }^{14}$ The delayed seeking of medical care is probably related to the population's limited knowledge about Loxosceles bites and their potential severity.

The aim of this article was to interpret, analyze and discuss aspects of the epidemiology and injuries resulting from spider bites in the southern region of Santa Catarina State, although the information provided by this study may be useful to various groups. Initially, these results could be used by the government to revise and improve the SINAN system; the study points out several failings resulting from the poor recording of accidents, from the victim to the Municipal Health Secretary and throughout the national system. Resources for helping the victims of venomous animals, together with preventive education, are sorely needed and must be rationally allocated in order to be effective and have the desired impact. The inadequacies in the epidemiological training of healthcare professionals highlighted in this study serve as a warning to teaching institutions. Although the data collected lack further epidemiological and especially clinical details, this does not affect the conclusions of the study, which can therefore be used in the planning of actions aimed at improving environmental health.

Authors' contributions: MPC, DCC and MSR designed the study and were responsible for the statistical analysis and interpretation of the data; MPC and DCC collected epidemiological, contextual and clinical data; MPC and DCC drafted and revised the manuscript. All authors read and approved the final manuscript. MPC and DCC are guarantors of the paper.

Acknowledgements: The authors would like to thank Coordenação de Aperfeiçoamento de Pessoal de Nível Superior (CAPES) and Conselho Nacional de Desenvolvimento Científico e Tecnológico (CNPq) for their financial support. The authors would also like to acknowledge the assistance of the Municipal Health Secretary of Criciúma, Santa Catarina.

Funding: MPC and DCC are supported by CAPES grants and MSR was supported by CNPq grants.

Conflicts of interest: None declared.

Ethical approval: Not required; the study is based on retrospective surveillance data.

\section{References}

1. Chippaux JP, Goyffon M. Epidemiology of scorpionism: a global appraisal. Acta Trop 2008;107:71-9.

2. White RR, Weber RA. Poisonous snakebite in central Texas. Ann Surg 1991;213:466-71.

3. Van den Enden E, Bottieau E. Envenoming by the viperid snake Eristicophis macmahonii. Toxicon 2005;46:918-20.

4. Plowman DM, Reynolds TL, Joyce SM. Poisonous snakebite in Utah. West J Med 1995;163:547-51.

5. Blaylock R. Epidemiology of snakebite in Eshowe, KwaZuluNatal, South Africa. Toxicon 2004;43:159-66.

6. Bortoletto ME, Bochner R. Drug impact in human poisoning in Brazil. Cad Saude Publica 1999;15:859-69.

7. FUNASA. Manual de diagnóstico e tratamento por animais peçonhentos. Brasília: Ministério da Saúde - Fundação Nacional de Saúde (FUNASA); 2001.

8. Cardoso JLC. Acidentes por animais peçonhentos na coordenação de zoonoses e animais peçonhentos-comentários e sugestões. Brasília: Ministério da Saúde; 1993 [mimeographed document].

9. Andrade RMG, Galati EAB, Tambourgi DV. Presença de Loxosceles similis Moenkhaus, 1898 (Araneae, Sicariidae) na Serra da Bodoquena, Estado de Mato Grosso do Sul, Brasil. Rev Soc Bras Med Trop 2001;34:275-7.

10. Cardoso DC, Cristiano MP, Raymundo MS, Costa S, Zocche JJ. Epidemiology and injuries (1994-2005) resulting from poisonous animals in southern Santa Catarina State, Brazil. $J$ Public Health 2007;15:467-72. 
11. Dufloth JH, Cortina N, Veiga M, Mior LC. Estudos básicos regionais de Santa Catarina [CD-ROM]. Florianópolis: EPAGRI Empresa de Pesquisa Agropecuária e Extensão Rural de Santa Catarina SA; 2005.

12. Pandolfo C, Braga HJ, Silva VP Jr, Massignan AM, Pereira ES, Thomé VMR. Atlas climatológico digital do Estado de Santa Catarina [CD-ROM]. Florianópolis: EPAGRI - Empresa de Pesquisa Agropecuária e Extensão Rural de Santa Catarina SA; 2002.

13. IBGE Cidades@. Rio de Janeiro: Instituto Brasileiro de Geografia e Estatística; 2007. http://www.ibge.gov.br/cidadesat/ topwindow.htm?1 [accessed 6 March 2009].

14. Sezerino UM, Zannin M, Coelho LK, Golçalves J Jr, Grando M, Mattosinho SG, et al. A clinical and epidemiological study of Loxosceles spider envenoming in Santa Catarina, Brazil. Trans $R$ Soc Trop Med Hyg 1998;92:546-8.

15. Lise F, Coutinho SED, Garcia FRM. Clinical features of aracneism in children and teenagers in Chapecó town, Santa Catarina State, Brazil. Acta Sci Health Sci 2006;28:13-6.

16. Marques-da-Silva E, Souza-Santos R, Fischer ML, Rubio GBG. Loxosceles spider bites in the state of Paraná, Brazil: 1993-2000. J Venom Anim Toxins incl Trop Dis 2006;12:110-23.

17. Silva PH, Silveira RB, Appel MH, Mangili OC, Gremski W, Veiga SS. Brown spiders and loxoscelism. Toxicon 2004;44:693-709.

18. Silva CJ, Jorge MT, Ribeiro LA. Epidemiology of snakebite in a central region of Brazil. Toxicon 2003;41:251-5.

19. Paula Neto JB, Ribeiro RSP, Luz JA, Galvão M, Carvalho SMD, Haddad V Jr. Clinical and epidemiological characteristics of injuries caused by venomous snakes observed at the hospital for tropical diseases of Araguaína, Tocantins State, Brazil, from 1995 to 2000. J Venom Anim Toxins incl Trop Dis 2005; 11:422-32.

20. Campbell MJ, Julious SA, Altman DG. Estimating sample sizes for binary, ordered categorical, and continuous outcomes in two group comparisons. BMJ 1995;311:1145-8.
21. Marques-da-Silva E, Fischer ML. Distribuição das espécies do gênero Loxosceles Heinecken \& Lowe, 1835 (Araneae; Sicariidae) no Estado do Paraná. Rev Soc Bras Med Trop 2005;38:331-5.

22. Steen CJ, Carbonaro PA, Schwartz RA. Arthropods in dermatology. J Am Acad Dermatol 2004;50:819-42.

23. Junghanss T, Bodio M. Medically important venomous animals: biology, prevention, first aid, and clinical management. Clin Infect Dis 2006;43:1309-17.

24. Carvalho MA, Nogueira F. Snakes from the urban area of Cuiabá, Mato Grosso: ecological aspects and associated snakebites. Cad Saude Publica 1998;14:753-63.

25. Cristiano MP, Cardoso DC. Honeybees and caterpillars: epidemiology of accidents involving these animals in the Criciúma region, southern Santa Catarina state, Brazil. J Venom Anim Toxins incl Trop Dis 2008;14:719-24.

26. Guia de vigilância epidemiológica. Brasília: Ministério da Saúde, Secretaria de Vigilância em Saúde; 2005.

27. Brazil TK, Almeida-Silva LM, Pinto-Leite CM, Lira-da-Silva RM, Peres MCL, Brescovit AD. Aranhas sinantrópicas em três bairros da cidade de Salvador, Bahia, Brasil (arachnida, araneae). Biota Neotrop 2005;5:1-7.

28. Diaz JH. The global epidemiology, syndromic classification, management, and prevention of spider bites. Am J Trop Med Hyg 2004;71:239-50.

29. Forrester MB, Stanley SK. Epidemiology of spider bites in Texas, 1998-2002. Public Health 2004;118:506-7.

30. Cardoso JCC, França FOS, Fan HW, Málaque CM, Haddad V Jr. Animais peçonhentos no Brasil. Biologia, clínica e terapêutica dos acidentes. São Paulo: Sarvier; 2003.

31. Souza ARB, Bührnheim PF, Lima CSC. Relato de um caso de latrodectismo ocorrido em Manaus, Amazonas, Brasil. Rev Soc Bras Med Trop 1998;31:95-8. 